\title{
PRINSIP DASAR MILLING DALAM SINTESIS MATERIAL
}

\author{
Annisa Awalliyah ${ }^{* 1}$, Hafizah Ikhwan ${ }^{2}$, Veny Nugiasari², Rahadian Zainul $^{2}$ \\ ${ }^{1}$ Laboratorium Kimia, FMIPA, Universitas Negeri Padang, Indonesia \\ ${ }^{2}$ Laboratorium Kimia, FMIPA, Universitas Negeri Padang, Indonesia \\ ${ }^{3}$ Laboratorium Kimia, FMIPA, Universitas Negeri Padang, Indonesia \\ ${ }^{4}$ Laboratorium Fisika, FMIPA, Universitas Negeri Padang, Indonesia
}

*Email : Hellomyfabulousday@gmail.com

\begin{abstract}
Abstrak Milling merupakan proses penguraian material yang menghasilkan bentukan bidang datar yang biasanya menggunakan proses dengan menggunakan bantuan mesin. Terdapat beberapa klasifikasi proses milling diantaranya Peripheral Milling, Face Milling, dan End Milling. Metode yang digunakan pada proses ini adalah metode pemotongan dan sistem pembagian pada mesin. Banyak faktor-faktor yang berpengaruh terhadap hasil dari proses milling ini seperti kecepatan, waktu, temperatur, tekanan, ukuran grinding ball, persentasi PCA (Process Control Agent), dan komposisi berat serbuk tersebut.
\end{abstract}

Kata kunci :Milling, metode, material, review

\section{PENDAHULUAN}

Milling merupakan proses penguraian material ${ }^{(10 ; 11)}$ yang menghasilkan bentukan bidang datar yang biasanya menggunakan proses dengan menggunakan bantuan mesin. Secara mekanik Milling merupakan teknik yang sederhana dan efektif ${ }^{(14)}$ untuk membuat ukuran kristal padat yang cukup besar menjadi lebih kecil tanpa melalui fasa penguapan atau reaksi kimia yang mana biasanya diperlukan dalam proses sintesa lainnya ${ }^{(17)}$. Untuk memulai proses milling ini digunakan cara yakni deformasi yang berulang-ulang dengan menghancurkan partikel serbuk sehingga partikel menjadi lebih kecil $^{(18)}$. Pada proses ini yang digunakan adalah vial dan bola-bola yang terbuat dari stainless steel yang diperkirakan dapat menyebabkan lepasnya unsur penyusu stainless steel ke dalam bahan objek ${ }^{(20)}$. Penggunaan teknik milling dapat diketahui dengan mendapatkan informasi tentang keberadaan unsur pengotor dalam sampel hasil proses milling ${ }^{(21)}$, maka didapatkan tingkat kemurnian dari sampel hasil proses milling tersebut ${ }^{(22)}$.

Proses pemesinan milling adalah proses penyayatan benda kerja menggunakan alat pemotong dan dilengkapi mata potong jamak yang berputar. Proses penyayatan dengan gigi potong yang banyak yang mengitari pahat ini dapat menghasilkan proses pemesinan lebih cepat. Permukaan yang disayat bisa berbentuk datar, menyudut, atau 
melengkung. Mesin (Gambar 1) yang digunakan untuk memegang benda kerja, memutar pahat, dan penyayatannya disebut mesin frais (Milling Machine).

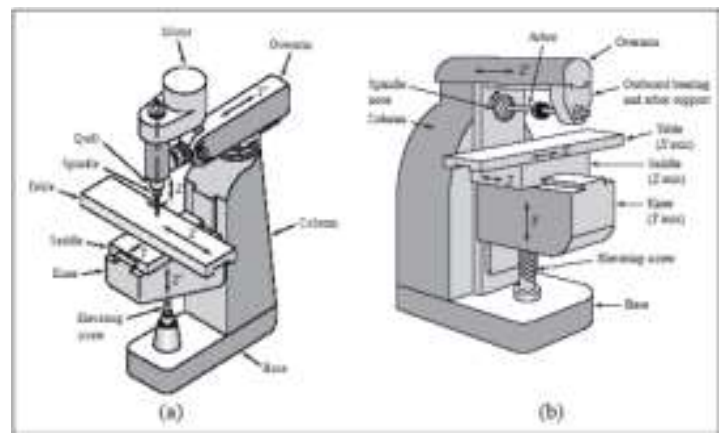

Gambar 1. Mesin Milling (Milling Frais) (23)

Terdapat beberapa klasifikasi milling yang mana pengklasifikasian ini ditentukan berdasarkan jenis pahat, arah penyayatan, dan posisi relatif pahat terhadap benda kerja. Diantara klasifikasi milling itu sendiri adalah :

1. Peripheral Milling (24)

Peripheral Milling ini sering disebut juga slab milling, permukaan yang difrais dihasilkan oleh gigi pahat yang terletak pada permukaan luar badan alat potongnya. Sumbu dari putaran pahat biasanya pada bidang yang sejajar dengan permukaan benda kerja yang disayat ${ }^{(25)}$.

2. Face Milling ${ }^{(26)}$

Pada frais muka, pahat dipasang pada spindel yang memiliki sumbu putar tegak lurus terhadap permukaan benda kerja ${ }^{(27)}$. Permukaan hasil proses frais ${ }^{(28)}$ dihasilkan dari hasil penyayatan oleh ujung dan selubung pahat.

3. End Milling

Pahat pada proses frais ujung biasanya berputar pada sumbu ${ }^{(29)}$ yang tegak lurus dengan permukaan benda kerja ${ }^{(30)}$. Pahat dapat digerakkan menyudut ${ }^{(31)}$. Gigi potong pada pahat terletak pada selubung pahat dan ujung badan pahat.

Dalam sintesis ${ }^{(32)}$ material yang sering digunakan dalam proses milling yakni menggunakan Ball Mill( ${ }^{(33)}$ dan CNC Mill. Ball Mill merupakan salah satu mesin pengolahan material ${ }^{(34)}$ yang berfungsi menghaluskan formula material tersebut dengan menggunakan bola-bola stainless steel ${ }^{(35)}$ yang ada pada tabung penghalusan. Ball Mill tersebut terbuat dari logam ${ }^{(36)}$ yang disyaratkan mempunyai karakteristik keras ${ }^{(37)}$ sekaligus tangguh (tidak mudah pecah) dan tahan korosi ${ }^{(38)}$ untuk menanggung beban dan lingkungan selama proses penggilingan materi. Banyak faktor-faktor yang berpengaruh terhadap hasil dari proses milling ini seperti kecepatan ${ }^{(39)}$, waktu, temperatur $^{(40)}$, tekanan, ukuran grinding ball, persentasi PCA (Process Control Agent), dan komposisi berat serbuk tersebut.

CNC (Computer Numerical Control) adalah mesin milling dimana pergerakan meja mesinnya dikendalikan dalam suatu program. Program tersebut berisi langkah-langkah perintah yang harus dijalankan oleh mesin CNC. Terdapat beberapa komponen mesin CNC antara lain meja mesin, spindel mesin, magasin tool, monitor, panel control, coolant hose. 


\section{METODE}

Metode $^{(41)}$ yang digunakan pada proses milling ditentukan berdasarkan arah relatif gerak makan meja mesin frais terhadap putaran pahat. Terdapat 2 macam metode yang digunakan pada proses ini :

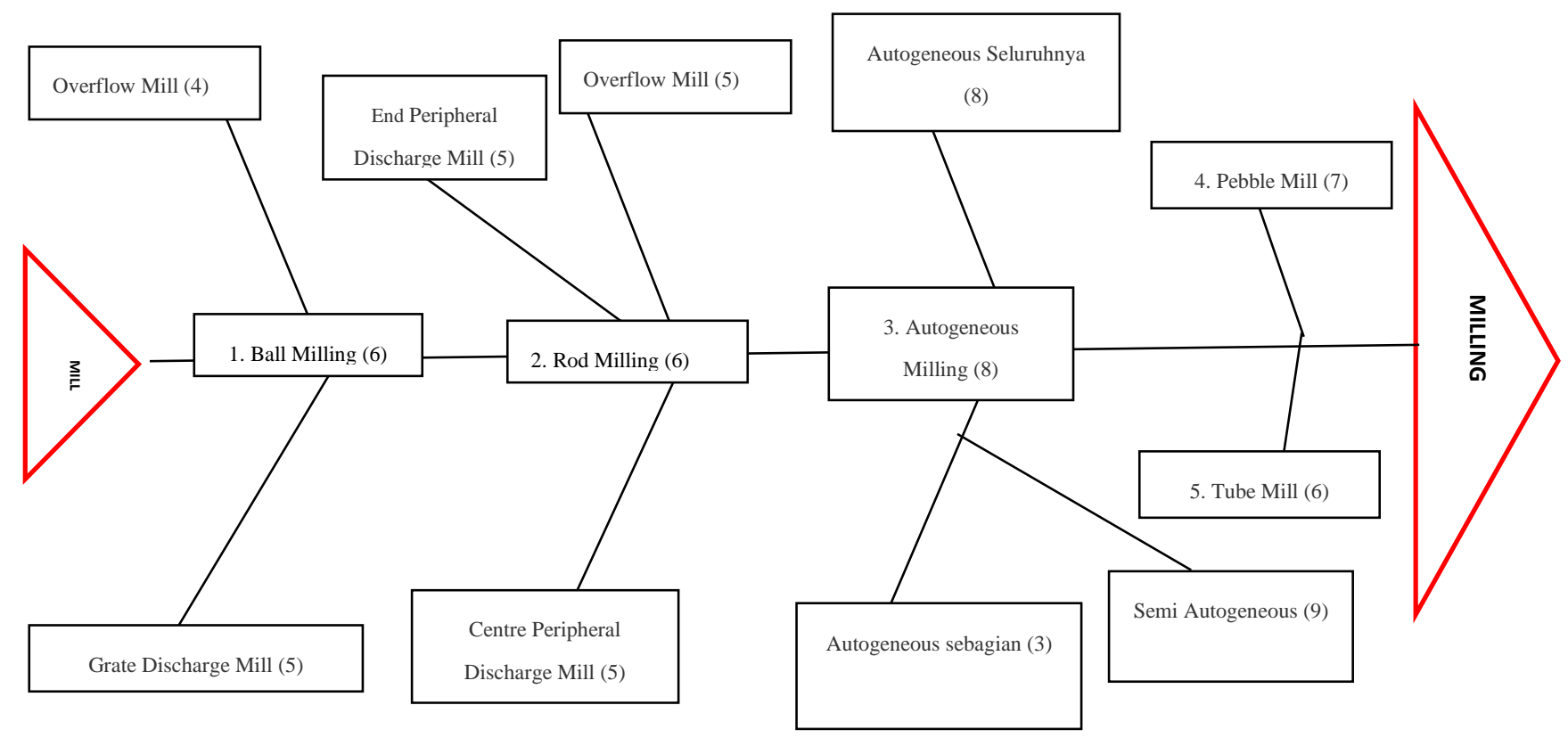




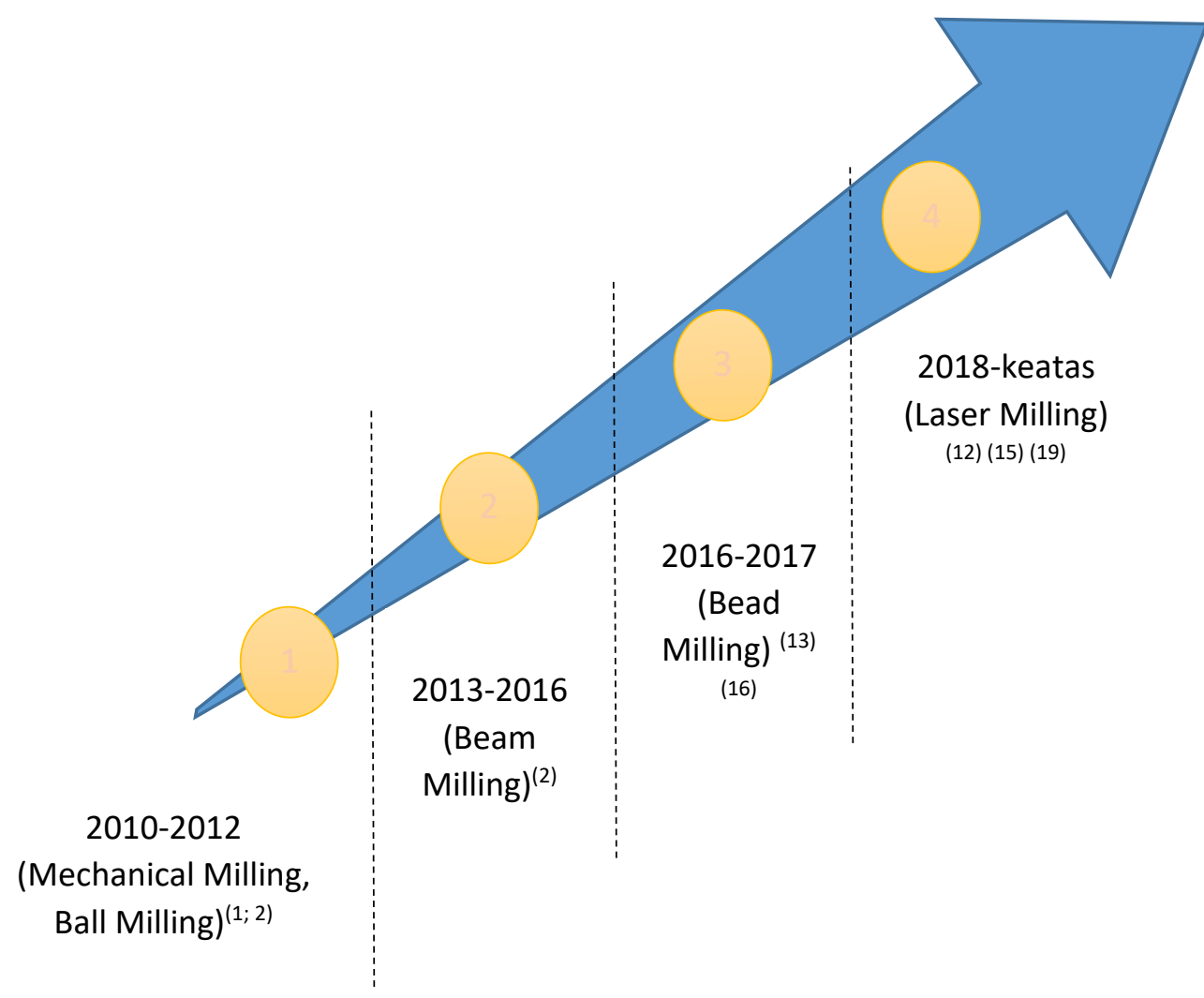

\section{PEMBAHASAN}

CNC mill merupakan salah satu mesin yang digunakan dalam proses milling. Mesin ini digunakan untuk mengerjakan satu jenis penyayatan dengan produktivitas/duplikasi yang sangat tinggi. CNC memiliki tenaga yang relatif besar sehingga menjadikan mesin ini banyak digunakan pada perusahaan manufaktur. Pada mesin ini dilengkapi dengan pengendali CNC untuk meningkatkan produktivitas dan fleksibilitas ${ }^{(17)}$. Dengan menggunakan alat kendali mesin ini waktu produksi menjadi lebih cepat dan hasilnya pun lebih bervariasi. Kelebihan lainnya pada mesin ini memiliki ketelitian yang tinggi. Namun beberapa perusahaan tidak dapat menggunakan mesin ini karena keterbatasan anggaran sehingga mereka lebih memilih mesin manual. Kekurangan pada mesin ini yakni dalam prosesnya kaku dan kekuatan penyayatannya yang rendah ${ }^{(20)}$.

Adapun prinsip kerja NC/CNC adalah :

1. Program $\mathrm{CNC}$ dibuat dengan cara diketik langsung pada mesin $\mathrm{CNC}$ menggunakan perangkat lunak pemograman CNC.

2. Prinsip kerja ini dikenal dengan G-Code yang kemudian dikirim oleh prosesor pada mesin CNC yang dapat menggerakkan perkakas melalui pengaturan motor servo pada proses permesinan untuk mendapatkan produk sesuai program.

Kebanyakan mesin penggilingan CNC ${ }^{(42)}$ (juga disebut pusat permesinan) adalah mesin penggilingan vertikal ${ }^{(43)}$ yang dikendalikan komputer dengan 
kemampuan untuk memindahkan poros secara vertikal ${ }^{(44)}$ sepanjang sumbuZ. Tingkat kebebasan ekstra ini memungkinkan penggunaannya dalam diesinking, aplikasi ukiran, dan permukaan 2.5D seperti patung relief . Ketika dikombinasikan dengan penggunaan alat ${ }^{(45)}$ berbentuk kerucut atau pemotong hidung bola , itu juga secara signifikan meningkatkan presisi penggilingan ${ }^{(46)}$ tanpa mempengaruhi kecepatan, memberikan alternatif yang hemat biaya untuk sebagian besar pekerjaan ukiran tangan permukaan datar.

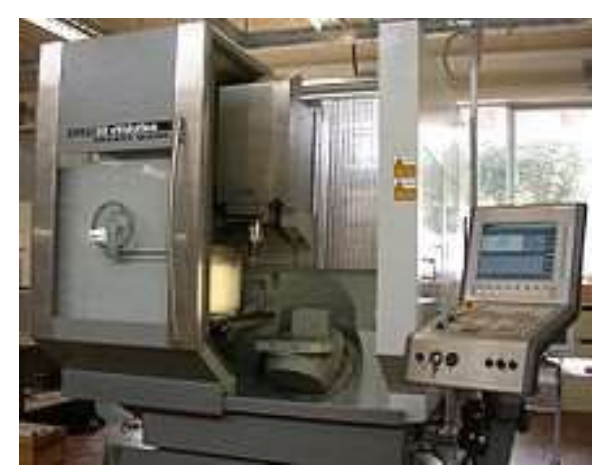

Gambar 2. Pusat permesinan lima sumbu dengan meja putar dan antarmuka komputer ${ }^{(47)}$

Mesin CNC bisa ada di hampir semua bentuk mesin manual ${ }^{(47)}$, seperti pabrik horizontal. Mesin milling CNC paling canggih , mesin multiasaks ${ }^{(48)}$, menambahkan dua kapak tambahan di samping tiga sumbu normal (XYZ). Mesin penggilingan horizontal juga memiliki sumbu $\mathrm{C}$ atau $\mathrm{Q}$, memungkinkan benda kerja yang dipasang secara horizontal untuk diputar, pada dasarnya memungkinkan pemintalan yang asimetris dan eksentrik. Sumbu kelima ( sumbu B) mengontrol kemiringan alat itu sendiri. Ketika semua sumbu ini digunakan bersama dengan satu sama lain, geometri yang sangat rumit, bahkan geometri organik seperti kepala manusia dapat dibuat dengan relatif mudah dengan mesin-mesin ini. Tetapi keterampilan untuk memprogram geometri semacam itu berada di luar jangkauan sebagian besar operator. Oleh karena itu, mesin penggilingan 5-sumbu praktis selalu diprogram dengan CAM .

Sistem operasi mesin tersebut adalah sistem loop tertutup dan berfungsi sebagai umpan balik. Mesin-mesin ini telah dikembangkan dari mesin NC (NUMERIC CONTROL) dasar. Suatu bentuk mesin NC yang terkomputerisasi dikenal sebagai mesin CNC.Serangkaian instruksi (disebut program) digunakan untuk memandu mesin untuk operasi yang diinginkan. Beberapa kode yang sangat umum digunakan, yang digunakan dalam program ini adalah:

G00 - traverse cepat

G01 - interpolasi alat secara linier.

G21 - dimensi dalam satuan metrik.

M03 / M04 - mulai spindel (searah jarum jam / berlawanan arah jarum jam).

T01 M06 - perubahan alat otomatis ke alat 1

M30 - akhir program.

Berbagai kode lain juga digunakan. Sebuah mesin CNC dioperasikan oleh operator tunggal yang disebut programmer. Mesin ini mampu melakukan berbagai operasi secara otomatis dan ekonomis. 
Dengan penurunan harga komputer dan perangkat lunak open source $\mathrm{CNC}$, harga masuk mesin CNC anjlok.

Pada mesin Ball Mill proses kerja pada mesin ini masih dikerjakan secara manual. Pada umumnya mesin ini dimiliki oleh perusahaan-perusahaan manufaktur dikarenakan anggaran biaya lebih efisien dibanding $\mathrm{CNC}^{(18)}$. Ball Mill terbuat dari logam yang mempunyai karakteristik keras sekaligus tangguh (tidak mudah pecah) dan tahan korosi untuk menanggung beban dan lingkungan selama proses penggilingan materi ${ }^{(18)}$. Namun, dalam proses pengerjaannya membutuhkan waktu yang cukup lama dibandingkan menggunakan $\mathrm{CNC}$ dan bentuk dari hasilnya pun kurang bervariasi. Prinsip kerja mesin milling tersebut adalah dengan memotong atau menyayat permukaan benda kerja dengan pisau bermata banyak yang berputar baik secara vertikal maupun horizontal dimana benda kerja ini dijepit pada ragum dan meja mesin digerakkan sejalan sumbu $X, Y, Z^{(20)}$.

Ball milling ini memiliki beberapa keunggulan dibandingkan dengan sistem yang lain ${ }^{(49)}$, biaya yang dikeluarkan menggunakan mesin ini rendah, cocok untuk melakukan proses penggilingan dalam jumlah yang banyak dan berkelanjutan. Demikian pula cocok untuk membuka serta menutup sirkuit pada penggilingan dan berlaku untuk semua jenis kekerasan suatu bahan ${ }^{(50)}$.

Ball milling ini juga biasa digunakan untuk menggiling ${ }^{(51)}$ material seperti batu bara, pigmen dan feldspar untuk tembikar. Penggilingan ini dapat dilakukan dalam keadaan basah maupun kering ${ }^{(52 ;}$ 53) namun dalam proses pembentukannya dilakukan dengan kecepatan yang rendah. Ball milling ini sudah terbukti efektif ${ }^{(54)}$ dalam memproduksi material amorf.

Hasil milling adalah material yang dihasilkan setelah mengalami perlakuan pada mesin milling yang meliputi pengurangan ukuran-ukuran karena pemakanan yang dilakukan oleh pahat. Hasil milling dapat dikatakan baik atau buruk didasarkan oleh dua faktor, yaitu ketepatan pada ukuran-ukurannya (kepresisian) dan tingkat kualitas permukaan yang dihasilkan. Melihat kedua faktor tersebut maka hasil milling dapat dikatakan baik apabila material ${ }^{(16 ; 28 ; 29 ; 45 ; 55 ; 56)}$ yang dihasilkan sesuai dengan ukuran ${ }^{(7 ; 57)}$ yang diinginkan dan permukaan material mempunyai tingkat kekasaran yang rendah (halus).

Berikut faktor yang mempengaruhi tingkat kekerasan hasil milling :

1. Bahan

Bahan berkaitan dengan sifat-sifat yang dimiliki oleh bahan itu sendiri, seperti : sifat keras, lunak, liat, dan lain-lain.

2. Pahat

Sifat-sifat bahan yang harus ada untuk setiap bahan pahat adalah mempu menahan pada pelunakan yang tinggi, harus lebih keras dari benda kerja dan mempunyai ketahanan yang tinggi untuk mengatasi retakan.

3. Pendingin 
Pendingin adalah suatu proses untuk mendinginkan panas yang terjadi akibat dua benda saling bergesekan, syarat-syarat pendingin sendiri meliputi : a) Mempunyai daya dingin yang baik

b) Mempunyai daya lumas yang baik

c) Mempunyai sifat netral terhadap benda kerja yakni menimbulkan karat ( korosi )

d) Tidak menganggu kesehatan

e) Tidak cepat memuai.

4. Tebal Pemakanan

Pemakanan adalah jarak yang ditempuh oleh pahat penyayat ketika langkah pemakanan berlangsung. Ketebalan pemakanan merupakan besaran yang menunjukan seberapa tebal penyayatan saat melakukan pemakanan.

5. Kecepatan Potong

Kecepatan potong merupakan kecepatan pemakanan pahat dalam satuan $\mathrm{m} / \mathrm{menit}$ atau $\mathrm{ft} / \mathrm{menit}$. (23)

Kekasaran permukaan merupakan salah satu penyimpangan yang disebabkan oleh kondisi potongan dari proses permesinan. Oleh karena itu, untuk memperoleh produk $^{(43 ; 57-59)}$ bermutu berupa tingkat kepresisian yang tinggi serta kekasaran permukaan yang baik, perlu didukung oleh proses permesinan yang tepat.

Rod mill sangat mirip dengan ball mill, tetapi pada rod mill menggunakan batang panjang yang digunakan untuk menggiling material ${ }^{(9-11 ; 13 ; 54 ; 60-66)}$. Batang tersebut menggiling material ${ }^{(3 ; 67 ; 68)}$ yang terdapat dalam penggilingan. Untuk mencegah terjadinya pengencangan terhadap muatan batang tersebut maka rasio diameter yang digunakan yakni 1,4 hingga 1,6. Rod Mills menerima material dengan ukuran kira-kira hingga $50 \mathrm{~mm}$ (2 inci) dan menghasilkan produk pada ukuran 3000 sampai $270 \mathrm{~mm}$ (-4 hingga -35 mesh).

Dari 3 jenis rod mill, yakni overflow ${ }^{(69)}$, end peripheral discharge, dan centre perifer, yang paling umum digunakan yakni overflow mill. Penggilingan dengan bahan basah pada rod mill biasanya digunakan dalam industry pengolahan mineral. Penggilingan kering itu digunakan di beberapa industry, namun penggilingan ini sebaiknya dihindari kecuali jika benar-benar diperlukan karena dapat memunculkan beberapa masalah. Rod mill ${ }^{(9 ; 70-72)}$ beroperasi dengan kecepatan yang lebih rendah dibandingkan ball mill, karena batangnya menggulung dan tidak mengalir.

Pada penggilingan dengan material yang sama, Rod mill menggunakan baja yang lebih sedikit dibandingkan ball mill ${ }^{(9 ; 73-78)}$ karena kecepatannya lebih rendah dibandingkan ball mill dan proses penggilingan yang lebih baik. Batang penggiling pada Rod mill harus dijaga dalam kondisi kerja yang baik, dan batang yang tidak bagus kinerjanya harus dilepas dari penggiling. Rod mill membutuhkan perhatian besar dari operator. Sangat penting sekali memastikan batang penggiling dalam posisi sejajar satu sama lain. Jika batang penggiling tidak sejajar, proses penggilingan tidak terjadi dan yang lebih penting batang tidak pada posisi yang seharusnya dan menjadi kusut. Panjang batang maksimum yakni 6,1 m. 

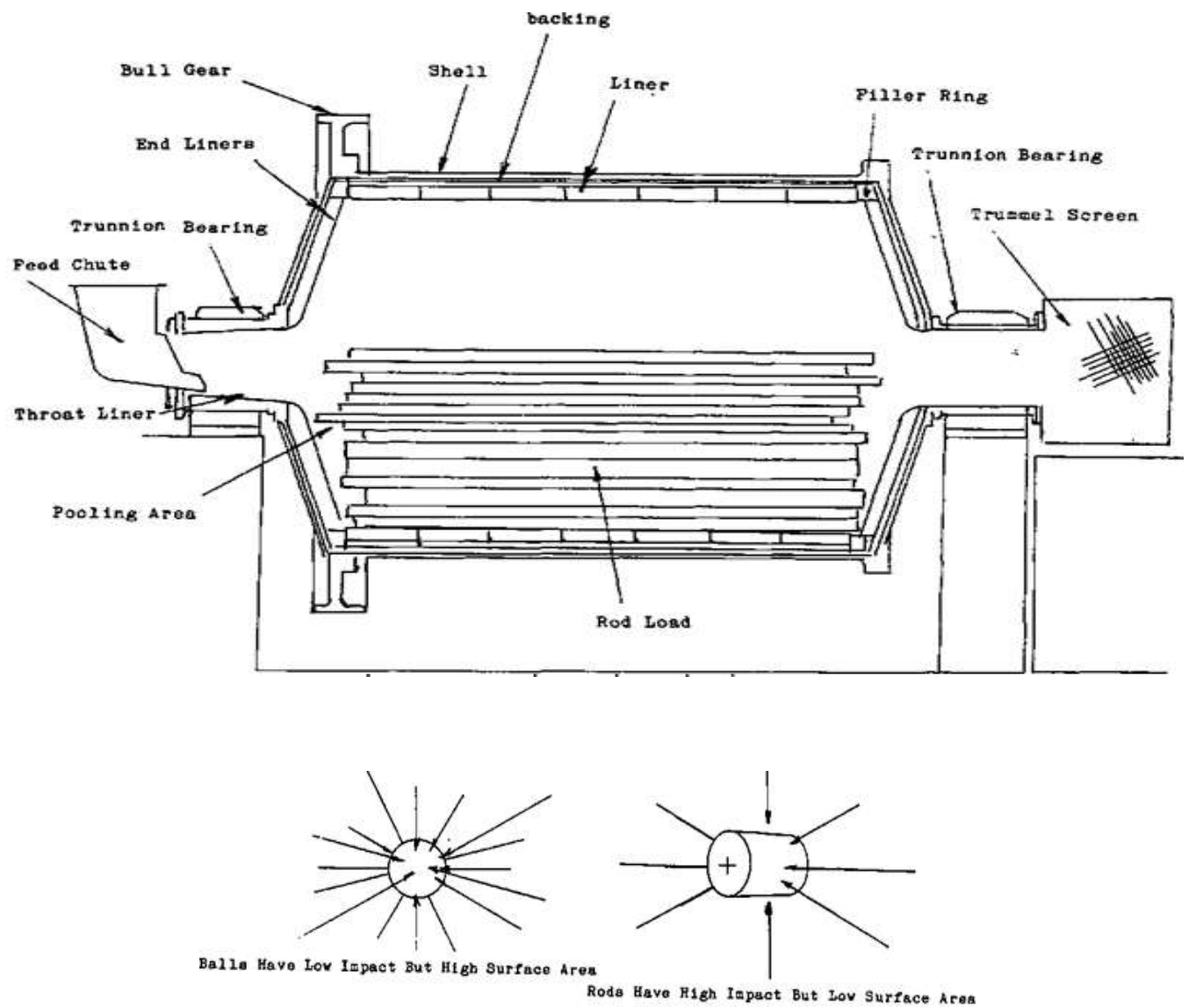

Gambar 3. Mesin Rod Mill (4)

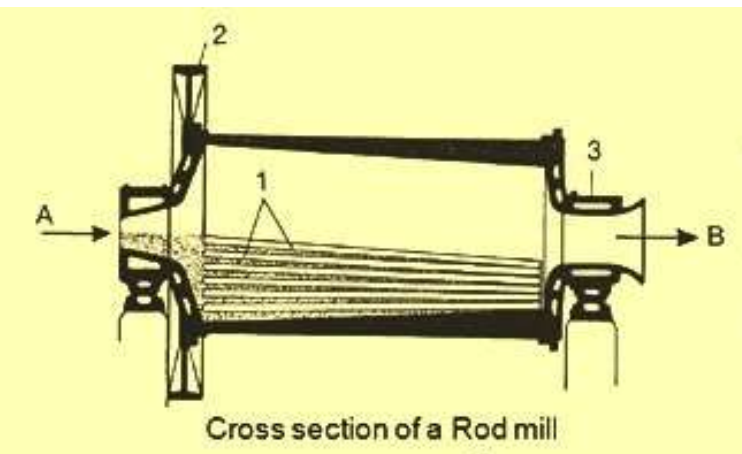

A. Material feed

B. Material outlet

1. Rods

2. Using mechanism

3. Bearings

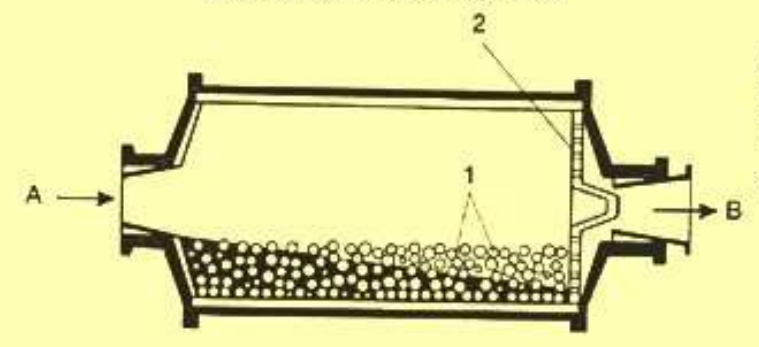

A. Material feed

B. Material outlet

1. Balls

2. Outlet screen

Cross section of a Ball mill

Gambar 4. Mesin Rod Mill dan Ball Mill (4) 


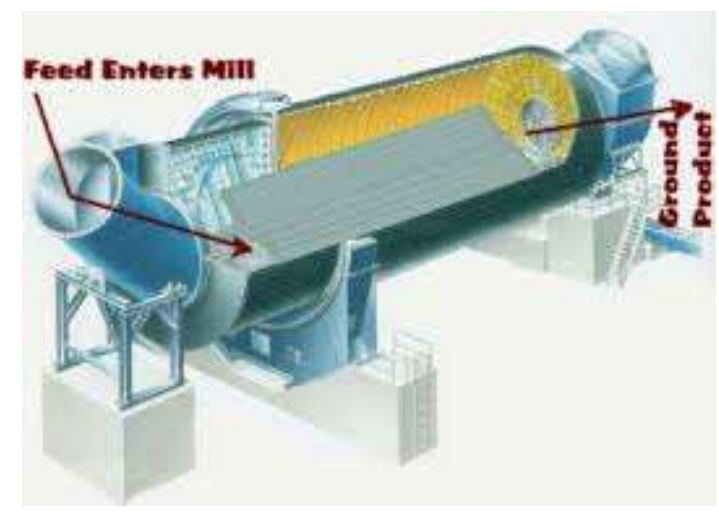

Gambar 5. Mesin Rod Mill (79)

Rod mill normalnya membawa 35 hingga $65 \%$ muatan batangan berdasarkan volume ${ }^{(80 ; 81)}$. Batas pada tingkat muatan adalah (1) menjaga trunnion ujung material terbuka sehingga material yang akan digiling akan masuk ke penggilingan, dan (2) menjaga muatan batang penggiling tetap rendah sehingga batang tidak akan bekerja dengan cara masuk ke bukaan pembuangan di mana mereka dapat menyebabkan kekusutan batang.

Autogeneous $^{(82)}$ atau autogenik mill disebut juga penggiling yang melalukan penggilingan material sendiri : drum yang berputar melemparkan batuan bijih yang lebih besar dalam gerakan kaskade yang menyebabkan pecahnya dampak batuan yang lebih besar dan penggilingan kompresif partikel yang lebih halus. Hal ini serupa dalam operasi untuk SAG mill seperti yang dijelaskan di bawah tetapi tidak menggunakan bola baja pada penggiling. Autogenous mill ini juga dikenal dengan sebutan ROM atau "Run Of Mine" grinding.

\section{Mesin penggilingan vertikal manual}

Komponen-komponen mesin penggilingan di atas dapat diorientasikan secara vertikal atau horizontal, menciptakan dua bentuk mesin penggilingan yang sangat berbeda. Mesin penggilingan horizontal menggunakan pemotong yang dipasang pada poros horizontal, yang disebut punjung, di atas benda kerja. Untuk alasan ini, penggilingan ${ }^{(6 ; 10 ; 11 ; 51 ; 64 ; 77 ; 78 ; 83-85)}$ horizontal kadang-kadang disebut sebagai penggilingan pancang. Arbor didukung di satu sisi oleh overarming, yang terhubung ke kolom, dan di sisi lain oleh spindel. Spindle digerakkan oleh motor dan karenanya memutar punjung. Selama penggilingan, pemotong berputar

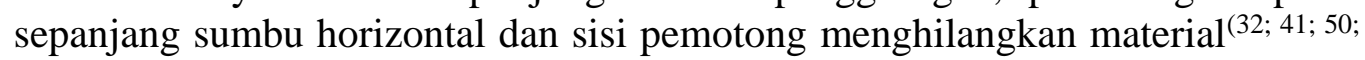
67; 68; 86-96) dari benda kerja. Sebuah mesin penggilingan vertikal, di sisi lain, mengarahkan pemotong secara vertikal. Pemotongnya diamankan di dalam potongan yang disebut collet ${ }^{(97 ; 98)}$, yang kemudian ditempelkan ke spindel yang berorientasi vertikal. Spindel terletak di dalam kepala penggilingan, yang dilekatkan pada kolom.Operasi penggilingan yang dilakukan pada mesin penggilingan vertikal menghilangkan material dengan menggunakan bagian bawah

dan

sisi

pemotong.

Mesin penggilingan juga dapat diklasifikasikan berdasarkan jenis kontrol yang digunakan ${ }^{(6 ; 99-101)}$. Sebuah mesin penggilingan manual membutuhkan operator 
untuk mengontrol gerakan pemotong selama operasi penggilingan. Operator menyesuaikan posisi pemotong dengan menggunakan engkol tangan yang menggerakkan meja, sadel, dan lutut. Mesin penggilingan juga dapat dikendalikan komputer ${ }^{(60)}$, dalam hal ini mereka disebut sebagai mesin penggilingan numerik komputer (CNC) milling machine. Mesin penggilingan CNC memindahkan benda kerja dan pemotong berdasarkan perintah yang terprogram dan menawarkan presisi yang sangat tinggi.Program yang ditulis sering disebut G-codes atau NC-codes. Banyak mesin penggilingan CNC juga mengandung sumbu gerak lain selain gerakan XYZ standar. Sudut spindel dan cutter dapat diubah, memungkinkan bentuk yang lebih rumit untuk digiling.

\section{KESIMPULAN}

Milling merupakan proses penguraian material yang menghasilkan bentukan bidang datar yang biasanya menggunakan proses dengan menggunakan bantuan mesin. Prinsip kerja mesin milling adalah dengan memotong atau menyayat permukaan benda kerja dengan pisau bermata banyak yang berputar baik secara vertikal maupun horizontal dimana benda kerja ini dijepit pada ragum dan meja mesin digerakkan sejalan sumbu X,Y,Z.

Referensi

1. Choi Y, Baik NI. 2012. Structure analysis and magnetic properties of nano-sized $\mathrm{Nb}(\mathrm{x}) \mathrm{Ni}(\mathrm{y}) \mathrm{Zn} 1-\mathrm{x}-\mathrm{yFe} 2 \mathrm{O} 4$ powders formed by combustion synthesis and mechanical milling. Journal of nanoscience and nanotechnology 12:1667-9

2. Jamali M, Gerhardt I, Rezai M, Frenner K, Fedder H, Wrachtrup J. 2014. Microscopic diamond solid-immersion-lenses fabricated around single defect centers by focused ion beam milling. The Review of scientific instruments 85:123703

3. Leung K. 1988. An energy based, ore specific model for autogenous and semi-autogenous grinding mills.

4. 2017. Ball Mills vs Rod Mills. www.911metallurgist.com/ball-mills-vs-rod-mills/

5. 2015. Overflow vs Grate Discharge Ball or Mill - Why Retrofit. https://www.911metallurgist.com/blog/overflow-vs-grate-discharge-ball-mills

6. Withington WH. 1938. Ball, Rod and Tube Mills. Industrial \& Engineering Chemistry 30:897-904

7. Fischer EK. 1941. Dispersion of Pigments by Ball and Pebble Mills. Industrial \& Engineering Chemistry 33:1465-71

8. Burgess D. 2012. A Method of Calculating Autogenous/Semi-Autogenous Grinding Mill Specific Energies Using a Combination of Bond Work Indices and Julius Kruttschnitt Parameters, then Applying Eficiency Factors. In 11th Mill Operators' Conference

9. Morrell S. 2004. Predicting the specific energy of autogenous and semi-autogenous mills from small diameter drill core samples. Minerals Engineering 17:447-51

10. Verma GC, Pandey PM. 2018. Machining forces in ultrasonic-vibration assisted end milling. Ultrasonics 
11. Caron V, Willart JF, Lefort R, Derollez P, Danede F, Descamps M. 2011. Solid state amorphization kinetic of alpha lactose upon mechanical milling. Carbohydrate research 346:2622-8

12. Nakamura N, Sugano N, Sakai T, Nakahara I. 2018. Does Robotic Milling For Stem Implantation in Cementless THA Result in Improved Outcomes Scores or Survivorship Compared with Hand Rasping? Results of a Randomized Trial at 10 Years. Clinical orthopaedics and related research

13. Anand C, Yamaguchi Y, Liu Z, Ibe S, Elangovan SP, et al. 2016. Pioneering In Situ Recrystallization during Bead Milling: A Top-down Approach to Prepare Zeolite A Nanocrystals. Sci Rep 6:29210

14. Chen L, Ding X, He Z, Fan S, Kunnath KT, et al. 2018. Surface engineered excipients: II. Simultaneous milling and dry coating for preparation of fine-grade microcrystalline cellulose with enhanced properties. International journal of pharmaceutics 546:125-36

15. James AE, Umamaheswari B, Shanthana Lakshmi CB. 2018. Comparative Evaluation of Marginal Accuracy of Metal Copings Fabricated using Direct Metal Laser Sintering, Computer-Aided Milling, Ringless Casting, and Traditional Casting Techniques: An In vitro Study. Contemporary clinical dentistry 9:421-6

16. Alfano KM, Chakraborty S, Tarasev M. 2016. Differences in bead-milling-induced hemolysis of red blood cells due to shape and size of oscillating bead. Biomed Mater Eng 27:405-12

17. Caballero ES, Cuevas FG, Ternero F, Astacio R, Montes JM, Cintas J. 2018. In Situ Synthesis of Al-Based MMCs Reinforced with AlN by Mechanical Alloying under NH(3) Gas. Materials 11

18. Ganive Pangesthi Aji HP. 2012. Pengaruh Milling Time Terhadap Pembentukan Fasa $\gamma$-MgAl Hasil Mechanical Alloying JURNAL TEKNIK POMITS Vol. 1: 1-5

19. Ohkuma K, Kameda T, Terada K. 2018. Five-axis laser milling system that realizes more accurate zirconia CAD/CAM crowns by direct milling from fully sintered blocks. Dental materials journal

20. Ernawati Jassin IY. 2014. EFEKTIFITAS KINERJA MESIN BALL MILL PADA FORMULA COKELAT BERDASARKAN PERBANDINGAN SUHU DAN RPM (ROTATION PER MINUTE) Jurnal Galung Tropika 3:116-26

21. El-Sayed TH, Aboelnaga A, El-Atawy MA, Hagar M. 2018. Ball Milling Promoted NHeterocycles Synthesis. Molecules 23

22. Dabrowski M, Gorski J. 2018. Influence of the Milling Tool Setup on Occupational Safety in Furniture Making. International journal of occupational safety and ergonomics : JOSE:1-30

23. Hari Yanuar AS, Ach. Kusairi 2014. PENGARUH VARIASI KECEPATAN POTONG DAN KEDALAMAN PEMAKANAN TERHADAP KEKASARAN PERMUKAAN DENGAN BERBAGAI MEDIA PENDINGIN PADA PROSES FRAIS KONVENSIONAL. Jurnal Ilmiah Teknik Mesin Unlam 3:27-33

24. Caggiano A, Improta I, Nele L. 2018. Characterization of a New Dry Drill-Milling Process of Carbon Fibre Reinforced Polymer Laminates. Materials 11

25. Ayuba EO, Bolu CA, John TM, Abioye AA. 2018. Dataset showing steel cold rolling process parameters for a 6-high cold rolling mill in Nigeria. Data in brief 18:891-901

26. Bozdemir M. 2018. Prediction of Surface Roughness considering Cutting Parameters and Humidity Condition in End Milling of Polyamide Materials. Computational intelligence and neuroscience 2018:5850432

27. Chen W, Liang Y, Hou X, Zhang J, Ding H, et al. 2018. Mechanical Grinding Preparation and Characterization of $\mathrm{TiO}(2)$-Coated Wollastonite Composite Pigments. Materials 11

28. Ali A, Hantanasirisakul K, Abdala A, Urbankowski P, Zhao MQ, et al. 2018. Effect of Synthesis on Performance of MXene/Iron Oxide Anode Material for Lithium-Ion Batteries. Langmuir

29. Baldo MP, Zaniqueli DA, Mill JG. 2018. Commentary: Peripheral and Central Aortic Pressure, Wave-Derived Reflection Parameters, Local and Regional Arterial Stiffness and Structural Parameters in Children and Adolescents: Impact of Body Mass Index Variations. High Blood Press Cardiovasc Prev 
30. Brassel J, Rohrssen F, Failing K, Wehrend A. 2018. Automated oestrus detection using multimetric behaviour recognition in seasonal-calving dairy cattle on pasture. New Zealand veterinary journal $66: 243-7$

31. Brook BW, Sleightholme SR, Campbell CR, Buettel JC. 2018. Deficiencies in estimating the extinction date of the thylacine with mixed certainty data. Conservation biology : the journal of the Society for Conservation Biology

32. H., Sanjaya, H., \& Zainul, R. (2016, August 30). Synthesis and Electrical Properties of ZnOITO and Al-ITO thin Film by Spin Coating Technique Through Sol Gel Process. https://doi.org/10.31227/osf.io/unrt4

33. Balaz M. 2018. Ball milling of eggshell waste as a green and sustainable approach: A review. Advances in colloid and interface science 256:256-75

34. Santos DFM, Soares O, Figueiredo JL, Pereira MFR. 2018. Effect of ball milling on the catalytic activity of cryptomelane for VOC oxidation. Environmental technology:1-14

35. Wang W, Yu H, Liu Y, Jiang X, Gao B. 2018. Trueness analysis of zirconia crowns fabricated with 3-dimensional printing. The Journal of prosthetic dentistry

36. Ohara Y, Hinokimoto A, Chen W, Kitao T, Nishiyama Y, et al. 2018. Formation of coordination polymer glass by mechanical milling: dependence on metal ions and molecular doping for $\mathrm{H}(+)$ conductivity. Chemical communications 54:6859-62

37. Sundum T, Szecsenyi KM, Kaewtatip K. 2018. Preparation and characterization of thermoplastic starch composites with fly ash modified by planetary ball milling. Carbohydrate polymers 191:198-204

38. Adelhelm P, Medenbach L, Escher I, Zedler L, Dietzek B, et al. 2018. Sulfur Spillover on carbon materials and possible impacts on metal-sulfur batteries. Angewandte Chemie

39. Bartos C, Pallagi E, Szabo-Revesz P, Ambrus R, Katona G, et al. 2018. Formulation of levodopa containing dry powder for nasal delivery applying the quality-by-design approach. European journal of pharmaceutical sciences : official journal of the European Federation for Pharmaceutical Sciences 123:475-83

40. Bartos C, Jojart-Laczkovich O, Katona G, Budai-Szucs M, Ambrus R, et al. 2018. Optimization of a combined wet milling process in order to produce poly(vinyl alcohol) stabilized nanosuspension. Drug design, development and therapy 12:1567-80

41. M., Sanjaya, H., \& Zainul, R. (2015, December 30). Characterization of napa soil and adsorption of $\mathrm{Pb}$ (II) from aqueous solutions using on column method.

https://doi.org/10.31227/osf.io/t8fh9

42. Albertin E, Sinatora A. 2001. Effect of carbide fraction and matrix microstructure on the wear of cast iron balls tested in a laboratory ball mill. Wear 250:492-501

43. Anhar, A., Sumarmin, R., \& Zainul, R. (2016, August 30). Measurement of Glycemic Index of West Sumatera Local Rice Genotypes for Healthy Food Selection. https://doi.org/10.31227/osf.io/tgy8h

44. Austin L, Bagga P, Celik M. 1981. Breakage properties of some materials in a laboratory ball mill. Powder Technology 28:235-43

45. Basset D, Matteazzi P, Miani F. 1993. Designing a high energy ball-mill for synthesis of nanophase materials in large quantities. Materials Science and Engineering: A 168:149-52

46. Bergersen O, Haarstad K. 2014. Treating landfill gas hydrogen sulphide with mineral wool waste (MWW) and rod mill waste (RMW). Waste management 34:141-7

47. Calka A, Radlinski A. 1991. Universal high performance ball-milling device and its application for mechanical alloying. Materials Science and Engineering: A 134:1350-3

48. Agre J, Elsley G, McFarlane D, Cheng J, Gunn B. Holonic control of a water cooling system for a steel rod mill. Proc. Computer Integrated Manufacturing and Automation Technology, 1994., Proceedings of the Fourth International Conference on, 1994:134-41: IEEE

49. Chen X, Yang J, Li S, Li Q. 2009. Disturbance observer based multi-variable control of ball mill grinding circuits. Journal of Process Control 19:1205-13

50. Zainul, Rahadian [et.al] (2015) Study of Pb(II) Biosorption from Aqueous Solution Using Immobilized Spirogyra Subsalsa Biomass. Journal of Chemical and Pharmaceutical Research, 11 (7). pp. 715-722. ISSN 0975-7384 
51. Cleary P. 1998. Predicting charge motion, power draw, segregation and wear in ball mills using discrete element methods. Minerals Engineering 11:1061-80

52. El-Eskandarany MS, Aoki K, Suzuki K. 1991. Difference between mechanical alloying and mechanical disordering in the amorphization reaction of A150Ta50 in a rod mill. Journal of alloys and compounds 177:229-44

53. El-Eskandarany MS, Sumiyama K, Aoki K, Suzuki K. Reactive ball mill for solid state synthesis of metal nitrides powders. Proc. Materials Science Forum, 1992, 88:801-8: Trans Tech Publ

54. Deng S, Zhang J, Ye L. 2009. Halloysite-epoxy nanocomposites with improved particle dispersion through ball mill homogenisation and chemical treatments. Composites Science and Technology 69:2497-505

55. Narayanan SS. 1985. Development of a laboratory single particle breakage technique and its application to ball mill modelling and scale-up.

56. Mishra B, Rajamani RK. 1992. The discrete element method for the simulation of ball mills. Applied Mathematical Modelling 16:598-604

57. chaidir, z., Fadjria, N., A., \& Zainul, R. (2016, December 5). Isolation And Molecular Identification Of Freshwater Microalgae In Maninjau Lake West Sumatera. https://doi.org/10.31227/osf.io/nbcuf

58. Zainul, R., Oktavia, B., Dewata, I., \& efendi, j. (2017, February 4). Studi Dinamika Molekular dan Kinetika Reaksi pada Pembelahan Molekul Air untuk Produksi Gas Hidrogen. https://doi.org/10.31227/osf.io/876s3

59. chaidir, z., Zainul, R., Nurakhbari, D., \& Salim, M. (2016, September 24). Optimization of Spirulina Platensis Culture for Antioxidant Production. https://doi.org/10.17605/OSF.IO/FD6E4

60. Kelsall D, Reid K, Restarick C. 1968. Continuous grinding in a small wet ball mill Part I. A study of the influence of ball diameter. Powder Technology 1:291-300

61. Stanley G. 1974. Mechanisms in the autogenous mill and their mathematical representation. Journal of the Southern African Institute of Mining and Metallurgy 75:77-98

62. Vickers G, Quan K. 1989. Ball-mills versus end-mills for curved surface machining. Journal of Engineering for Industry 111:22-6

63. Rajamani RK, Herbst JA. 1991. Optimal control of a ball mill grinding circuit-I. Grinding circuit modeling and dynamic simulation. Chemical Engineering Science 46:861-70

64. Tamaki S, Hisamatsu M, Teranishi K, Adachi T, Yamada T. 1998. Structural change of maize starch granules by ball-mill treatment. Starch-Stärke 50:342-8

65. Ramasamy M, Narayanan S, Rao CD. 2005. Control of ball mill grinding circuit using model predictive control scheme. Journal of Process Control 15:273-83

66. Yasthopi A. 2015. Photoelectrosplitting water for hydrogen production using illumination of indoor lights. Journal of Chemical and Pharmaceutical Research 7:246-56

67. Kurniawati, D., Lestari, I., Harmiwati., Sy, S., Chaidir, Z., Munaf, E., Zein, R., Aziz, H., \& Zainul, R. (2015). Biosorption of Pb (II) from Aqueous Solutions Using Column Method by Lengkeng (Euphoria Loogan Lour) Seed and Shell. Journal of Chemical and Pharmaceutical Research, 7(12) : 872-877. ISSN : 0975-7384.

68. Zainul, R., Oktavia, B., Dewata, I., Efendi, J. Thermal and Surface Evaluation on The Process of Forming a $\mathrm{Cu} 2 \mathrm{O} / \mathrm{CuO}$ Semiconductor Photocatalyst on a Thin Copper Plate. https://doi.org/10.1088/1757-899X/335/1/0120349

69. Tuncay KS, Gunbey E, Simsek G, Acar B, Karasen RM. 2015. Comparison of autogeneous and homogeneous nasal dorsal onlay grafts in an experimental design. European archives of oto-rhino-laryngology : official journal of the European Federation of Oto-Rhino-

Laryngological Societies 272:619-25

70. Mankosa M, Adel G, Yoon R. 1986. Effect of media size in stirred ball mill grinding of coal. Powder technology 49:75-82

71. McFarlane D, Marett B, Elsley G, Jarvis D. Application of holonic methodologies to problem diagnosis in a steel rod mill. Proc. Systems, Man and Cybernetics, 1995. Intelligent Systems for the 21st Century., IEEE International Conference on, 1995, 1:940-5: IEEE 
72. Mio H, Kano J, Saito F. 2004. Scale-up method of planetary ball mill. Chemical engineering science 59:5909-16

73. 1895. Rod-mill reel. Google Patents

74. Rowland C. 1982. Selection of rod mills, ball mills, pebble mills and regrind mills. Design and installation of comminution circuits:393-438

75. Rodríguez B, Rantanen T, Bolm C. 2006. Solvent-Free Asymmetric Organocatalysis in a Ball Mill. Angewandte Chemie 118:7078-80

76. Rodriguez B, Bruckmann A, Bolm C. 2007. A highly efficient asymmetric organocatalytic aldol reaction in a ball mill. Chemistry-A European Journal 13:4710-22

77. Thorwirth R, Stolle A, Ondruschka B. 2010. Fast copper-, ligand-and solvent-free Sonogashira coupling in a ball mill. Green Chemistry 12:985-91

78. Thorwirth R, Stolle A, Ondruschka B, Wild A, Schubert US. 2011. Fast, ligand-and solventfree copper-catalyzed click reactions in a ball mill. Chemical Communications 47:4370-2

79. 2012. Rod Mills, How Do They Work? www.mine-engineer.com/mining/rodmill.htm

80. Heyes G, Kelsall D, Stewart P. 1973. Continuous grinding in a small wet rod mill Part I. Comparison with a small ball mill. Powder Technology 7:319-25

81. Herbst J, Fuerstenau D. 1980. Scale-up procedure for continuous grinding mill design using population balance models. International Journal of Mineral Processing 7:1-31

82. Maurice D, Hawk J. 1999. Simultaneous autogenous milling and ferric chloride leaching of chalcopyrite. Hydrometallurgy 51:371-7

83. PA M, Lim K, AD R, Lee Y. 2003. Computational exploration of microstructural evolution in a medium C-Mn steel and applications to rod mill. ISIJ international 43:1421-30

84. Yang J, Li S, Chen X, Li Q. 2010. Disturbance rejection of ball mill grinding circuits using DOB and MPC. Powder Technology 198:219-28

85. Wang Y-F, Chen R-X, Wang K, Zhang B-B, Li Z-B, Xu D-Q. 2012. Fast, solvent-free and hydrogen-bonding-mediated asymmetric Michael addition in a ball mill. Green Chemistry 14:893-5

86. Zainul, Rahadian [et.al] (2015) Design of Photovoltaic Cell with Copper Oxide Electrode by Using Indoor Lights. Research Journal of Pharmaceutical, Biological and Chemical Sciences, 6 (4). pp. 353-361. ISSN 0975-8585

87. Zainul R, Alif A, Aziz H, Arief S. 2015. DISAIN GEOMETRI REAKTOR FOTOSEL CAHAYA RUANG. Jurnal Riset Kimia 8:131

88. Zainul R. 2015. Disain dan Modifikasi Kolektor dan Reflektor Cahaya pada Panel Sel Surya $\mathrm{Al} / \mathrm{Cu} 2 \mathrm{O}-\mathrm{Gel} \mathrm{Na} 2 \mathrm{SO} 4$.

89. Zainul, R., Alif, A., Aziz, H., Arief, S., \& Darajat, S. (2015, Juli). Modifikasi dan Karakterisasi I-V Sel Fotovoltaik $\mathrm{Cu}_{2} \mathrm{O} / \mathrm{Cu}-\mathrm{Gel} \mathrm{Na}_{2} \mathrm{SO}_{4}$ Melalui Iluminasi Lampu Neon. Juli 2015, Padang.

90. Zainul, R., Alif, A., Aziz, H., Arief, S., \& s. (2015, October 22). Photoelectrosplitting Water Mechanism at Carbon Electrode Surface using Indoor lights.

https://doi.org/10.31227/osf.io/vexq8

91. Zainul, R. (2016, November 19). Effect of Temperature and Particle Motion against the ability of ZnO Semiconductor Photocatalyst in Humic Acid.

https://doi.org/10.31227/osf.io/wnygb

92. Zainul, R. (2016, September 24). Determination of the half-life and the quantum yield of $\mathrm{ZnO}$ semiconductor photocatalyst in humic acid. https://doi.org/10.31227/osf.io/e8a9x

93. Zainul, R., \& Dewata, I. (2015, December 29). Determination of pH-BOD-COD and degradation in batang arau watersheds at Padang city. https://doi.org/10.31227/osf.io/efdzj

94. M., Yani, S. R., \& Zainul, R. (2017, September 4). Aktivasi Tanah Napa dan Pengaruhnya Terhadap Adsorpsi Ion Timbal (II)/ Pb2+. https://doi.org/10.31227/osf.io/ps523

95. Zainul, R. (2016, December 18). Design and Modification of Copper Oxide Electrodes for Improving Conversion Coefficient Indoors Lights (PV-Cell) Photocells. https://doi.org/10.31227/osf.io/pgn84

96. Mawardi, M., Deyndha, D., Zainul, R., \& Zalmi, R. (2018). Characterization of PCC Cement by Addition of Napa Soil from Subdistrict Sarilamak 50 Kota District as Alternative Additional Material for Semen Padang. https://doi.org/10.1088/1757-899X/335/1/012034 
97. Gavin FJ. 1947. Tube mill and method of operating same, including discharging. Google Patents

98. Gao M, Forssberg E. 1995. Prediction of product size distributions for a stirred ball mill. Powder Technology 84:101-6

99. Higgins WC. 1994. Weld quality monitoring and control system for a tube mill. Google Patents

100. Hoşten Ç, Özbay C. 1998. A comparison of particle bed breakage and rod mill grinding with regard to mineral liberation and particle shape effects. Minerals engineering 11:871-4

101. Içli B, Christinat N, Tönnemann J, Schüttler C, Scopelliti R, Severin K. 2009. Synthesis of molecular nanostructures by multicomponent condensation reactions in a ball mill. Journal of the American Chemical Society 131:3154-5

102. Liza, Y. M., Yasin, R. C., Maidani, S. S., \& Zainul, R. (2018, October 9). SOL GEL : PRINCIPLE AND TECHNIQUE (A REVIEW). Retrieved from osf.io/dnp8r

103. Febriani, S. S., Yolanda, T., Arianti, V. A., \& Zainul, R. (2018, October 12). A Review Solid Stated : Principles and Methode. Retrieved from osf.io/b9qzv

104. P, Oki M, Laura G A, Apri Y M S, and Rahadian Zainul. 2018. "A Review Grinding : Teknik Dan Prinsip Dasar Pada Pengolahan Material.” OSF. October 12. doi:10.17605/OSF.IO/4RY96.

105. Dinata, Agil A, Abel M Rosyadi, Syukri Hamid, and Rahadian Zainul. 2018. "A Review CHEMICAL VAPOR DEPOSITION : PROCESS AND APPLICATION.” OSF. October 15. doi:10.17605/OSF.IO/4X63F. 